\title{
Oral Capsule Dosage Form
}

National Cancer Institute

\section{Source}

National Cancer Institute. Oral Capsule Dosage Form. NCI Thesaurus. Code C91165.

A capsule intended for administration through the mouth. 